\title{
Petrography and provenance of floor sediments from the Loutra Almopias Cave (Pella, Macedonia, Greece)
}

\author{
Ioannis Georgiadis ${ }^{1,2}$, Katerina Chatzopoulou ${ }^{1}$, Nikolaos Kantiranis ${ }^{1}$, \\ Ioakeim Ioakeimidis $^{1}$, and Ananias Tsirambides ${ }^{1 *}$ \\ ${ }^{1}$ School of Geology, Aristotle University of Thessaloniki, 54124 Thessaloniki, Greece \\ ${ }^{2}$ Per Aarsleff A/S, Industriholmen 2, 2650 Hvidovre, Denmark
}

\begin{abstract}
Thirty seven floor sediment samples of Upper Pleistocene age from the Loutra Almopias Cave were collected from different beds and stratigraphic columns on the basis of their induration grade, grain distribution, and paleontological findings. Channel facies make up the bulk of the clastic sediments found in the cave passages. Slackwater facies compose the final layer of all the stratigraphic sections of the examined cave. The floor sediments are mineralogically immature, since they contain many ferromagnesian minerals, feldspars (especially plagioclase) and quartz. The extensive presence of silicate minerals means that the phyllites, gneisses, schists, ophiolitic rocks and the clastic Mariam Formation of the Almopia Zone are the main detrital load source, along with the flysch of the neighboring Pelagonian Zone. The presence of sand-sized grains, pebbles and cobbles of dolomitic or calcitic composition also designates the carbonate rocks of the Almopia and Pelagonian Zones as primary sources. The dolomite and calcite content of secondary chemical origin in the cave sediments is very limited. Kutnohorite, isomorphous with dolomite, was found for first time in a Greek cave. The provenance of the sediments is mixed; they are composed mainly of the weathering materials of the Alpine metamorphic basement and the carbonate rocks outcropping adjacent to the cave. The sediments were transported and deposited inside the cave, after rapid weathering and erosion of the surrounding rocks, under a tectonically active regime. The mineralogical variation in the stratigraphic columns demonstrates variations in the clastic load, due to the different weathering intensity periods. Most of the sediments are fluvial deposits, and one is considered a glacial deposit. Fossils of Lepus timidus (mountain hare) found within the cave represent the southernmost record of this species in Europe. Its presence signifies a cool phase at the end of the last glacial period before the onset of the warm Holocene Epoch.
\end{abstract}

Keywords: channel and slackwater facies, fluvial, kutnohorite, mountain hare, Loutra Almopias Cave, Greece Received 13 June 2019; Revised 10 September 2019; Accepted 10 September 2019

Citation: Georgiadis I., Chatzopoulou K., Kantiranis N., loakeimidis I. and Tsirambides A., 2019. Petrography and provenance of floor sediments from the Loutra Almopias Cave (Pella, Macedonia, Greece). International Journal of Speleology, 48 (3), 237-248. Tampa, FL (USA) ISSN 0392-6672 https://doi.org/10.5038/1827-806X.48.3.2271

\section{INTRODUCTION}

The abundance of a terrigenous mineral in a given sedimentary rock depends mainly on three factors, namely its availability in the parent rocks of the source area, its mechanical stability and its chemical stability (Folk, 1974). According to Suttner (1974) the factors that combine to produce detrital assemblages found in modern and ancient sediments include source-rock composition, tectonics, climate and relief. Reineck \& Singh (1986) consider the mechanism of transportation and deposition, along with climate and source areas, as the most important factors for the accumulation of a sedimentary deposit. In a more descriptive way, Pettijohn et al. (1987) consider provenance as the paleogeography of a region, the identification of possible source areas for the clastic material and the revealing of details about the paleocurrents and the paleoslope.

Most of the transported and deposited clastic sediments in a cave tend to be episodic. Although the overall mix of these materials depends greatly on the weathering products in the source area distinctly different facies are formed inside the cave depending on flow dynamics. Based on transport mechanisms the sediments deposited in a cave may be distinguished in the facies: channel, thalweg, slackwater, diamicton, and backswamp (Bosch \& White, 2004). Sediment 
input, sediment removal and chemical precipitation, processes that have occurred repeatedly in the past, are related to distinct paleoclimate and hydrological conditions that have yielded complex sediment assemblages in many caves (Auler et al., 2009).

The mountains around the Mediterranean Sea were repeatedly glaciated during the Pleistocene (2.58 Ma to 11,700 yr BP) (Hughes \& Woodward, 2016). The geomorphological and sedimentological record of glaciations in these mountains provides valuable information on past climates because the presence of glaciers is closely related to atmospheric air temperature and moisture supply (Hughes \& Woodward, 2016).

In Greece, mountain glaciations appear to have been quite extensive along the mountain range of Pindus and on Mount Olympus during the Middle and Upper Pleistocene. Cirques are the most characteristic landforms of glaciated mountains and usually are used as evidence of occurrence of former glaciers (Woodward \& Hughes, 2011; Bathrellos et al., 2014). Bathrellos et al. (2017) studied a total of 227 inactive cirques, of limestone lithology in majority, and mapped them across the mountains of Greece (Fig. 1).

Four discrete phases of Pleistocene glacial activity have been recorded on Mount Smolikas $(2,637 \mathrm{~m})$, the $2^{\text {nd }}$ highest mountain in Greece (Bathrellos et al., 2014). Paleoclimatic reconstructions based on modern

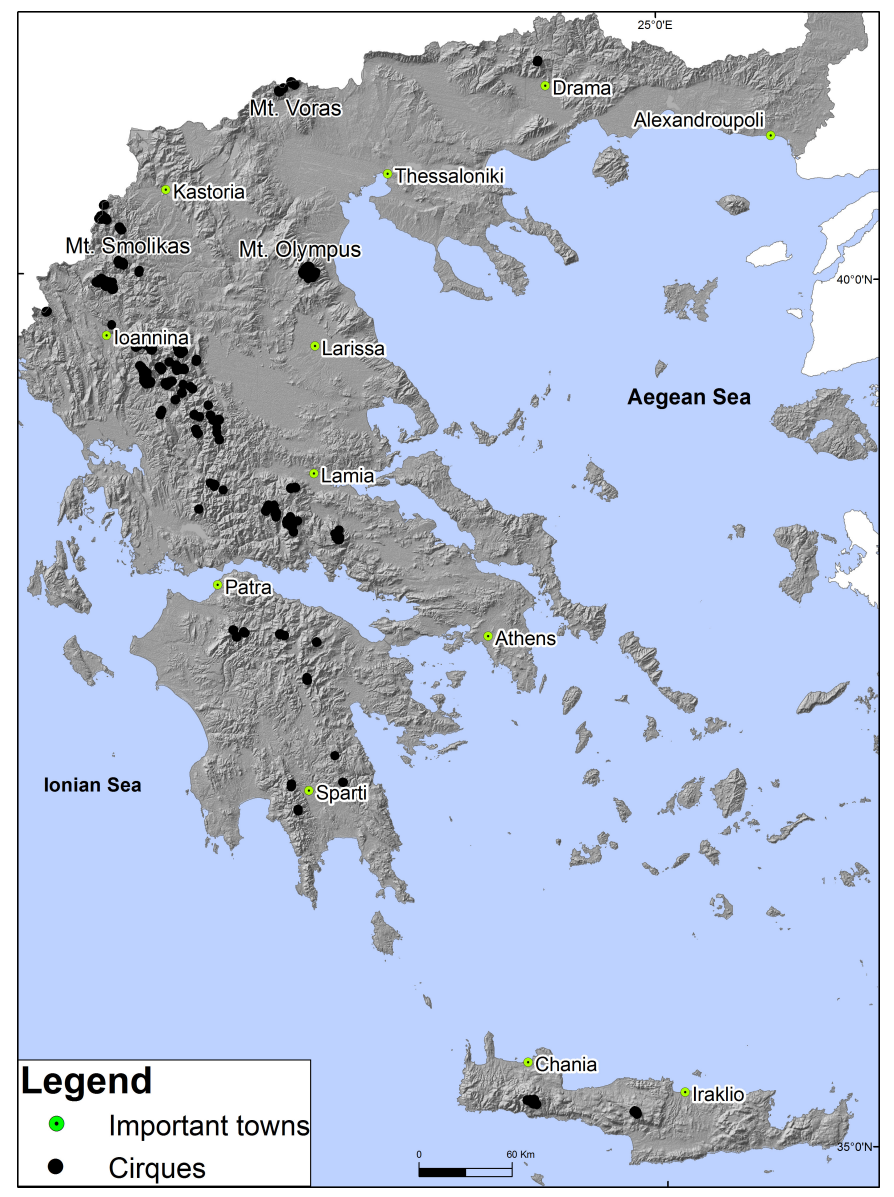

Fig. 1. Topographic map of Greece with the location of cirques (black circles): 1) Mount Falakro; 2) Mount Voras; 3) Mount Olympus; 4) Mount Grammos; 5) Mount Vasilitsa; 6) Mount Smolikas; 7) Mount Tymphi; 8) Mount Athamanon; 9) Mount Vardousia; 10) Mount Giona; 11) Mount Parnassus; 12) Mount Erymanthos; 13) Mount Aroania (or Chelmos); 14) Mount Taygetus; 15) Mount Lefka Ori; 16) Mount Idi (modified from Bathrellos et al., 2017). glacier- and rock glacier-climate relationships suggest that mean annual temperatures during the last phase of glacier activity in the Pindus Mountains were $6.3^{\circ} \mathrm{C}$ cooler than present (Hughes et al., 2006). The last glacial advance in Greece correlates well with global cooling during Heinrich Event 1, between 14,310 \pm $200 \mathrm{y}$ and $13,960 \pm 260 \mathrm{yr} \mathrm{BP}$ (Hughes et al., 2006). Evidence of former equilibrium line elevations on Mount Olympus $(2,918 \mathrm{~m})$, the highest mountain in Greece, point to more extensive Pleistocene glaciations and far colder climates than previous studies have indicated (Smith et al., 2006). These findings are supported by the record of glacial deposits both on the mountain and across the adjacent piedmont (Smith et al., 2006).

The Loutra Almopias Cave (LAC) (Fig. 2) is located in Pella Macedonia (Northern Greece) on the eastern slopes of Mount Voras $(2,524 \mathrm{~m})$, about $120 \mathrm{~km}$ northwest of Thessaloniki. It is developed at the north side of the V-shaped gorge of Thermopotamos Stream near the site of the local spa at an altitude of 540 m (Tsoukala et al., 2006). Formerly it was known as Bear Cave of Almopia Speleopark (Tsirambides, 2006) or Loutra Arideas Bear Cave (Tsoukala et al., 2006). Its total surface area is $820 \mathrm{~m}^{2}$ and its longest corridor is $129 \mathrm{~m}$.

Early study of sediments collected from different depths of one excavation site at the floor of the Loutra Almopias Cave confirmed the extensive presence of Ca-Mg primary and secondary minerals (Tsirambides, 2006). This mineral assemblage is indicative of the composition of source rocks in the broader area.

Karst morphology and fluid inclusion study confirmed the hypogene-hydrothermal origin of all the caves in the Almopia speleopark. Cave morphology is dominated by cupolas, phreatic bridges, ridges and "windows", fracture guided passages, pendants, pseudonotches, false-floors and spongeworks, indicating that speleogenesis was largely due to slowly flowing hot water bodies (Lazaridis, 2006). Phreatic calcite from an adjacent cave was analyzed on the basis of fluid inclusions to investigate the physicochemical conditions of the flowing water bodies. This calcite was formed at temperatures ranging from 120 to $189^{\circ} \mathrm{C}$, with a peak around $150^{\circ} \mathrm{C}$. The fluids were dominated by $\mathrm{NaCl}$ of very low salinities (0.2-1.0 wt\% $\mathrm{NaCl}$ equiv.) showing dominance of meteoric waters (Lazaridis \& Melfos, pers. comm.).

The age range of the fossil-bearing beds from the cave is from $32 \mathrm{ka} \mathrm{BP}$ to a maximum of $43 \mathrm{ka} \mathrm{BP}$ (Rabeder at al., 2006; Zisi et al., 2010). Samples of these Late Pleistocene bear bones were studied by carbon and oxygen isotope analysis for paleoclimatic reconstruction indicating that colder climatic conditions prevailed in the area in relation to modern time (Zisi et al., 2010).

Excavations in the cave for paleontological research during the period 1992-2006 yielded more than 15,000 fossil remains from large and small mammals (Tsoukala et al., 2006). The micromammal fossils contained in the sediment deposits of this cave were studied in detail by Chatzopoulou (2014) who presented original data on its stratigraphy, taphonomy, and paleoenvironment. 

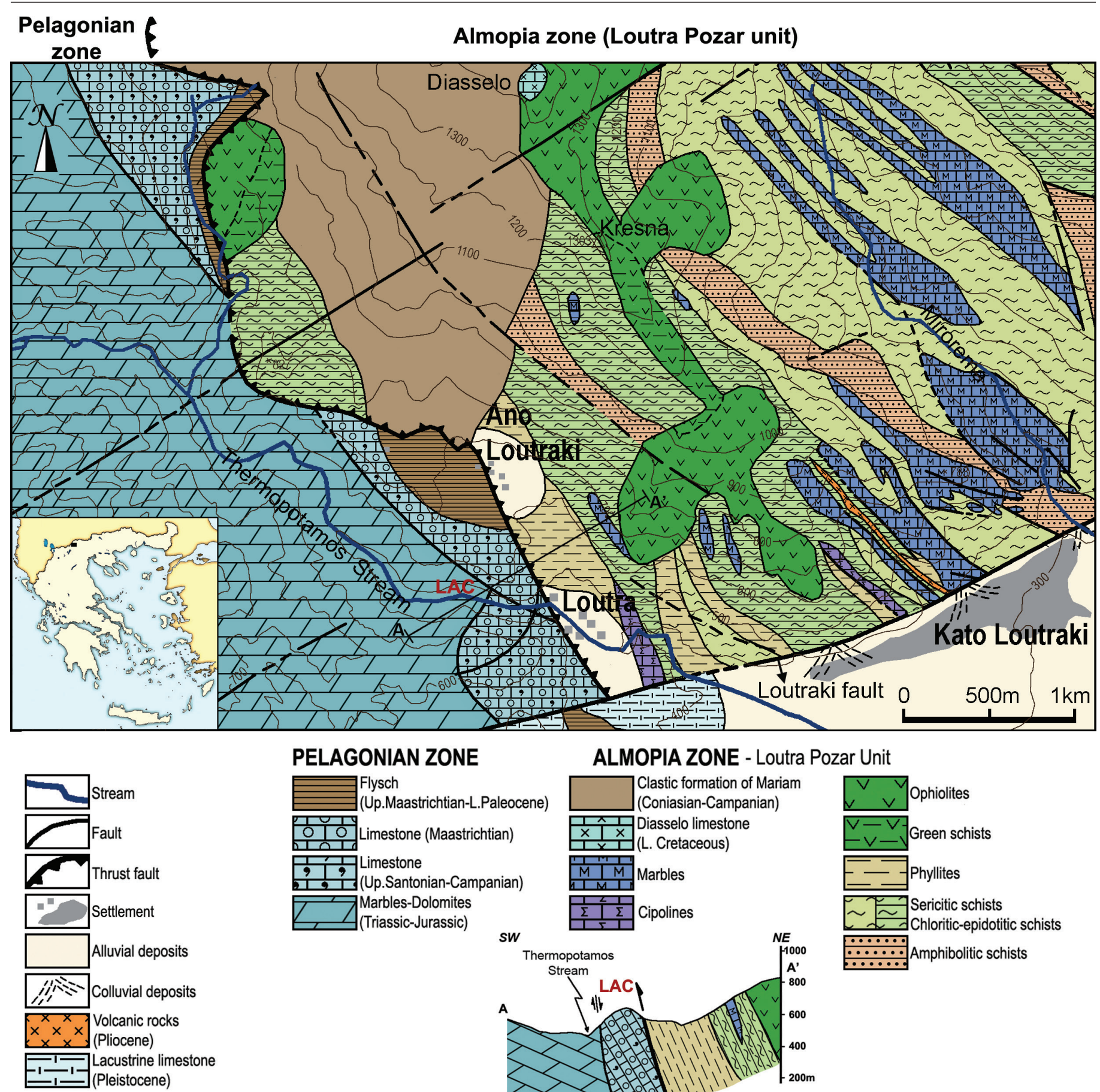

PELAGONIAN ZONE
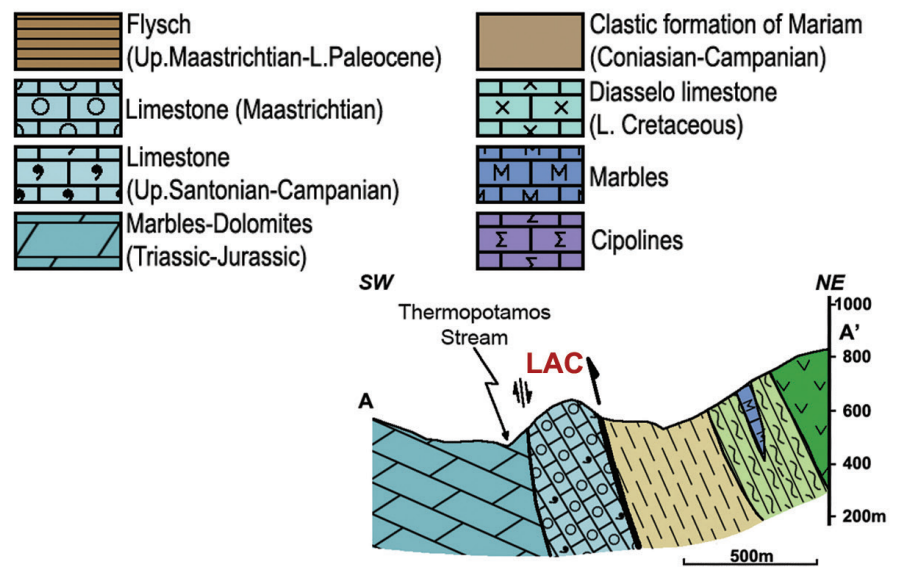

ALMOPIA ZONE - Loutra Pozar Unit

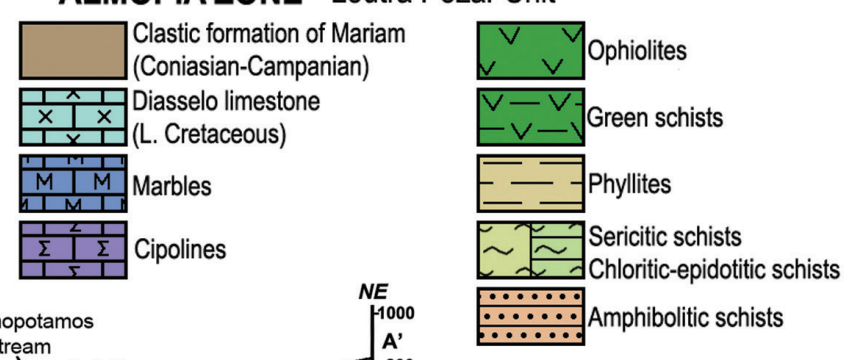

Fig. 2. Geological map of the study area and position of LAC (Loutra Almopias Cave) (adapted from Mountrakis, 1976).

In the Upper Pleistocene the supply of the detrital sediments to the cave started through site LAC Ic, which probably was an entrance at that time. In the Holocene, the initial entrance was already blocked by rock falls and large boulders collapsed from the cave ceiling. Afterwards, chemical sedimentation took place inside the cave, resulting in the formation of various speleothems (i.e., stalactites, stalagmites, curtains, gours, flowstones, etc.) (Kabouroglou et al., 2006; Chatzopoulou, 2014).

The present work is a detailed textural and mineralogical study of the sediments deposited inside the cave, designed to enhance the paleontological research of other academic researchers. The results of this study will be directly relevant for the interpretation of the taphonomical history of the thousands of fossils collected from the cave (Chatzopoulou, 2014).
Furthermore, the climatic conditions, under which the sediments were accumulated, along with their provenance, are important constraints on the origins of the fossils.

\section{GEOLOGICAL SETTING}

The study area is on the eastern margin of the Pelagonian Zone and the western margin of the Almopia Zone (Fig. 2, Mountrakis, 1976). The Pelagonian Zone consists of two areas: one with marbles and dolomitic/micaceous marbles of Triassic to Jurassic age and another with transgressional limestones of Upper Cretaceous age and flysch of Upper Cretaceous-Lower Paleocene age. The Almopia Zone and especially its Unit of Loutra Almopias (Pozar), is composed of a metamorphic basement with 
phyllites, sericitic schists, greenschists, amphibolitic schists, gneisses, marbles, cipolines and ophiolitic rocks of Paleozoic to Triassic age, the limestone of Diasselo of Lower Cretaceous age and the clastic formation of Mariam of Upper Cretaceous age. The whole Loutra Almopias Unit moved westwards on a thrust fault over carbonates and submarine fans of the Pelagonian Zone (Fig. 2, Mountrakis, 1976).

Throughout the Almopia Zone many occurrences of Pliocene volcanic rocks are found, with the volcanic centers being located to the northern region of the zone (Mount Voras) and the volcaniclastics to the southern region (Almopia Plain) (Eleftheriadis, 1977). The volcanic rocks are rhyolites, dacites, trachytes, latites, andesites and sossonites, belonging to the high $\mathrm{K}$ calcalkaline series. These rocks, being acid to intermediate, are rich in plagioclase, sanidine, hornblende, clinopyroxene and biotite (Eleftheriadis, 1977; Kolios et al., 1980; Vougioukalakis, 1994).

\section{MATERIALS AND METHODS}

Thirty seven fine to medium grained sediment samples were collected from different beds of the stratigraphic columns (Fig. 3). The criteria for their selection were the induration grade of the beds, the grain distribution and the paleontological findings inside them. They were analyzed in detail, both texturally and mineralogically. The samples were ground in a mortar to disaggregate them and left to dry at room temperature (Jackson, 1974) prior to X-ray diffraction (XRD) analysis. Powder X-ray diffraction was performed in a Philips diffractometer with $\mathrm{Ni}$ filtered $\mathrm{CuK}_{\mathrm{a}}$ radiation. Randomly oriented mounts of the untreated samples were scanned over the interval $3-63^{\circ} 2 \theta$ at a scanning speed of $1.2^{\circ}$ per minute. In addition, parallelly oriented, glycolated and heated at $550^{\circ} \mathrm{C}$ for 2.5 hours mounts of selected fine grained $(<20 \mu \mathrm{m})$ samples were scanned over the interval 3-33 ${ }^{\circ}$ $2 \theta$ at the same scanning speed. Semi-quantitative estimates of the minerals present are based on peak heights and intensity factors of the XRD patterns, using the methods described by Hower et al. (1976) and Moore \& Reynolds (1997). Any gravel load in the samples (grains with diameter $>2 \mathrm{~mm}$ ) was previously removed. Five rich-in-gravel samples from column N10 (chamber LAC I) were separated into consecutive size fractions by sieving for their textural properties to be studied. These samples were selected for textural analysis, because this deposit demonstrates the greatest lithological variety of all the chambers and also, it is located in the centre of the cave. In addition, the $<20 \mu \mathrm{m}$ fraction of six fine grained samples obtained from different beds, was studied in detail using powder X-ray diffraction. This fraction was acquired using gravimetric methods (Jackson, 1974).

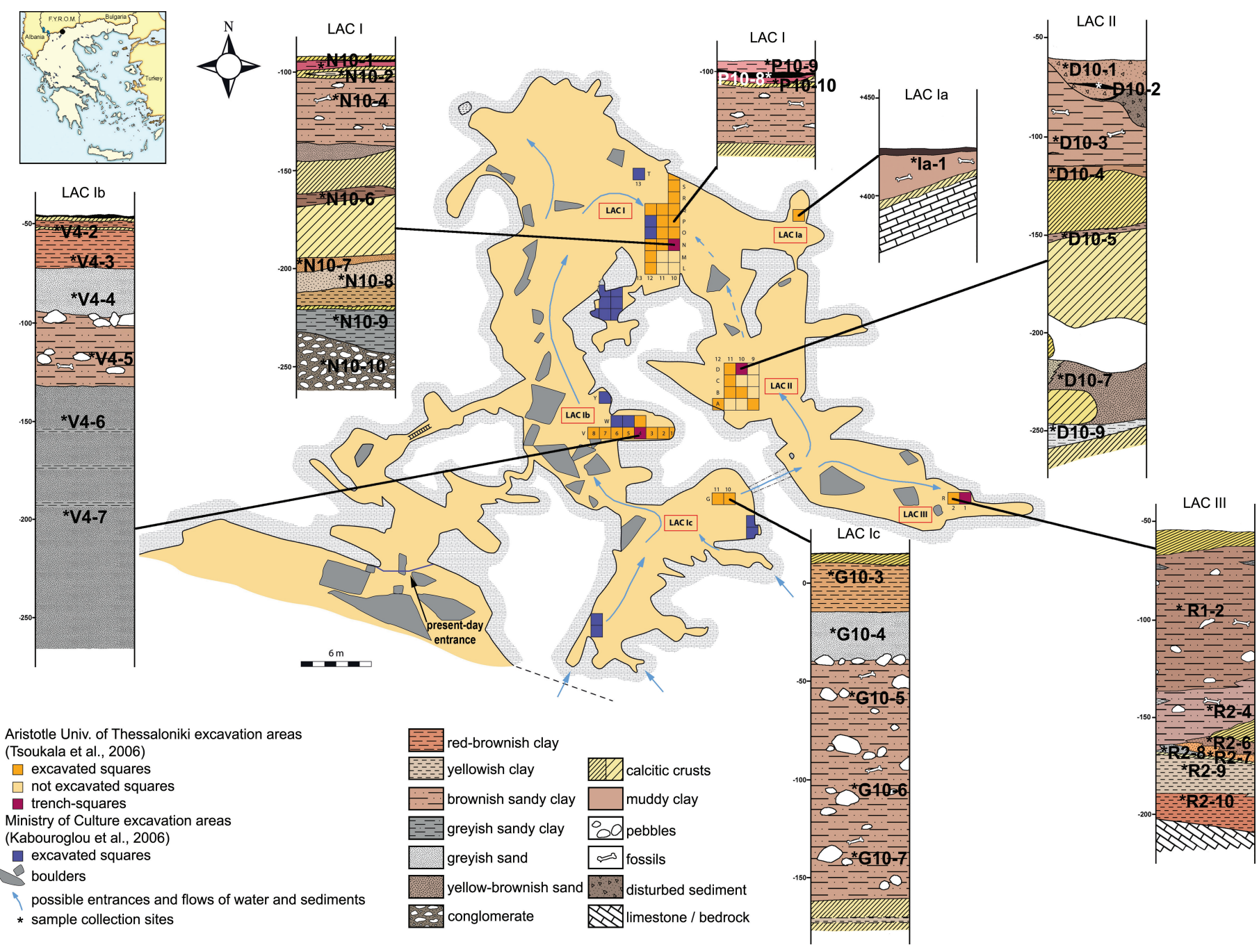

Fig. 3. Ground plan of Loutra Almopias Cave (LAC) with the excavated sites in the chambers (Kabouroglou \& Chatzitheodorou, 1999; illustration by G. Withalm; modified). Positions of the stratigraphic columns and of the samples collected from different beds of each column are shown. Depth in cm. 
In this way the mineralogical composition of this fraction of the samples was estimated. In both cases, prior to their separation, no chemical treatment was applied to the samples.

\section{RESULTS}

\section{Textural characteristics}

Macroscopically the samples analyzed are mainly gravels to fine grained sands, with a few samples being more clayey. In some cases relatively mud-rich samples abruptly overlie sandy ones, a fact indicative of the end in a detrital load supply and the beginning of a new cycle of accumulation under different hydraulic conditions.

The textural properties of detrital sediments depend on weathering and depositional processes, as well as on the source material. All of these are reflected through the size and shape of the grains and the sorting and skewness of the sediments (Blatt et al., 1980). The statistical parameters of grain size populations of the gravel-bearing samples from column LAC I (N10) were determined according to Folk et al. (1970) and are presented in Table 1. The largest number of different sediment beds (12) exist at this column (Fig. 3). The samples analyzed have poor to very poor sorting $\left(\sigma_{\mathrm{I}}=1\right.$ to 2.04). Samples N10-1 and N10-10 are fine skewed, N10-4 and N10-8 present almost symmetrical skewness and sample N10-7 is coarse skewed. The poor degree of sorting of the sand-sized grains, the pebbles and cobbles contained, along with the presence of mud in most of the samples, designate them as texturally submature.

The characterization of the cave sediments, on the basis of gravel/sand/silt/clay ratios, is presented in Table 2. In Figures 4 and 5 the textural classification of these samples is shown. Specifically, samples containing gravels are classified as gravelly sands, with the exception of sample N10-8 which is slightly gravelly sand and N10-10, which is sandy gravel (Fig. 4). The gravel-free samples are classified as silty sands, muddy sands, sandy muds, sandy silts, muds and one sample as silt (R2-10) (Fig. 5).

Table 1. Statistical parameters of grain size populations of the samples containing gravels from the column LAC I (N10), according to Folk et al. (1970).

\begin{tabular}{|l|c|c|c|c|c|}
\cline { 2 - 6 } \multicolumn{1}{c|}{} & N10-1 & N10-4 & N10-7 & N10-8 & N10-10 \\
\hline G (wt.\%) & 13.94 & 14.28 & 4.99 & 0.54 & 33.84 \\
\hline $\mathrm{M}($ wt.\%) & 1.16 & 3.18 & 6.80 & 7.52 & 1.91 \\
\hline $\mathrm{S}($ wt.\%) & 84.90 & 82.54 & 88.21 & 91.94 & 64.26 \\
\hline Mo $(\Phi)$ & $0 \& 3$ & $-3 \& 0.8$ & $-2 \& 3.3$ & 3.2 & $-0.2 \& 3.9$ \\
\hline $\mathrm{Md}(\Phi)$ & 0.4 & 0.5 & 2.5 & 2.8 & -0.4 \\
\hline $\mathrm{M}_{\mathcal{Z}}(\Phi)$ & 0.66 & 0.76 & 2.03 & 2.8 & 0.05 \\
\hline $\mathrm{QD}_{\Phi}(\Phi)$ & 1.35 & 1.18 & 1.09 & 0.65 & 1.21 \\
\hline$\sigma_{\mathrm{I}}(\Phi)$ & 1.69 & 2 & 1.73 & 1 & 2.04 \\
\hline $\mathrm{Sk}_{\mathrm{I}}$ & 0.29 & -0.01 & -0.35 & -0.05 & 0.25 \\
\hline $\mathrm{K}_{\mathrm{G}}$ & 0.79 & 1.28 & 0.99 & 1.11 & 1.11 \\
\hline
\end{tabular}

$\Phi=-\log _{2} \delta$ ( $\delta=$ diameter in $\left.\mathrm{mm}\right) ; \mathrm{G}=$ weight percent of gravel; $\mathrm{M}=$ weight percent of mud (silt + clay); $\mathrm{S}=$ weight percent of sand; $\mathrm{Mo}=$ mode $; \mathrm{Md}=$ median; $\mathrm{M}_{\mathrm{Z}}=$ graphic mean; $\mathrm{QD}_{\phi}=$ quartile deviation at $\Phi ; \sigma_{\mathrm{I}}=$ inclusive graphic standard deviation; $\mathrm{Sk}_{\mathrm{L}}=$ inclusive graphic skewness; $\mathrm{K}_{\mathrm{G}}=$ graphic kurtosis .
Table 2. Textural classification based on the gravel/sand/silt/clay percentages of the cave sediments analyzed, according to Folk et al. (1970)

\begin{tabular}{|l|c|c|c|c|c|}
\hline \multicolumn{1}{|c|}{ Sample } & Gravel & Sand & Silt & Clay & Classification \\
\hline N10-1 & 14 & 85 & \multicolumn{2}{|c|}{$1^{*}$} & Gravelly sand \\
\hline N10-4 & 14 & 83 & \multicolumn{2}{|c|}{$3^{*}$} & Gravelly sand \\
\hline N10-7 & 5 & 88 & \multicolumn{2}{|c|}{$7^{*}$} & Gravelly sand \\
\hline N10-8 & 1 & 92 & \multicolumn{2}{|c|}{$7^{*}$} & $\begin{array}{c}\text { Slightly } \\
\text { gravelly sand }\end{array}$ \\
\hline N10-10 & 34 & 64 & \multicolumn{2}{|c|}{$2^{*}$} & Sandy gravel \\
\hline P10-10 & - & 28 & 71 & 1 & Sandy silt \\
\hline V4-2 & - & 3 & 63 & 34 & Mud \\
\hline V4-3 & - & 32 & 49 & 19 & Sandy silt \\
\hline V4-4 & - & 59 & 36 & 5 & Silty sand \\
\hline V4-5 & - & 30 & 35 & 35 & Sandy mud \\
\hline V4-6 & - & 74 & 22 & 4 & Silty sand \\
\hline D10-3 & - & 21 & 30 & 49 & Sandy mud \\
\hline D10-4 & - & 60 & 26 & 14 & Muddy sand \\
\hline D10-8 & - & 84 & 15 & 1 & Silty sand \\
\hline G10-3 & - & 8 & 59 & 33 & Mud \\
\hline G10-4 & - & 61 & 36 & 3 & Silty sand \\
\hline G10-5/7 & - & 57 & 23 & 20 & Muddy sand \\
\hline R2-6 & - & 31 & 44 & 25 & Sandy mud \\
\hline R2-7 & - & 71 & 24 & 5 & Silty sand \\
\hline R2-8 & - & 71 & 24 & 5 & Silty sand \\
\hline R2-9 & - & 12 & 80 & 8 & Sandy silt \\
\hline R2-10 & - & 3 & 75 & 22 & Silt \\
\hline
\end{tabular}

*(Silt+Clay)

Most of the sediments analyzed are fluvial in origin. The majority of them present bimodal grain populations, a characteristic of river sands. Pebbles and cobbles, red-brownish to grey-whitish in color, exist in some beds of the chambers excavated. Their lithology varies greatly. More specifically, in the fossil-bearing bed V4-5 (LAC Ib) pebbles and cobbles of dolomites, marbles, limestones, sandstones and ophiolitic rocks are found. In the fossil-bearing beds G10-5, G10-6 and G10-7 (LAC Ic) pebbles and cobbles of dolomites, marbles, greenschists, black limestones and ophiolitic rocks are found, whereas in the fossil-bearing bed R1-2 (LAC III) only pebbles of marbles are found. The sediments are generally loose or slightly compacted, with the exception of the samples obtained from the upper beds that exhibit great induration. The distribution of coarse gravel, pebbles and cobbles in the different stratigraphic columns is presented in Fig. 3. This distribution is greatly influenced by the dynamics of the water flow entering the cave passages.

The depositional environment of some samples was estimated using the discrimination diagram of $\mathrm{Pe} \&$ Piper (1975). Samples N10-1, N10-4 and N10-10 are classified as fluvial deposits, whereas samples N10-7 and N10-8, obtained from a depth of about $200 \mathrm{~cm}$ below the reference-zero point of the cave (usually the floor elevation at the cave entrance), are mudflow and glacial deposits, respectively (Fig. 6). Probably, some more sediments from other chambers could be of glacial origin. 


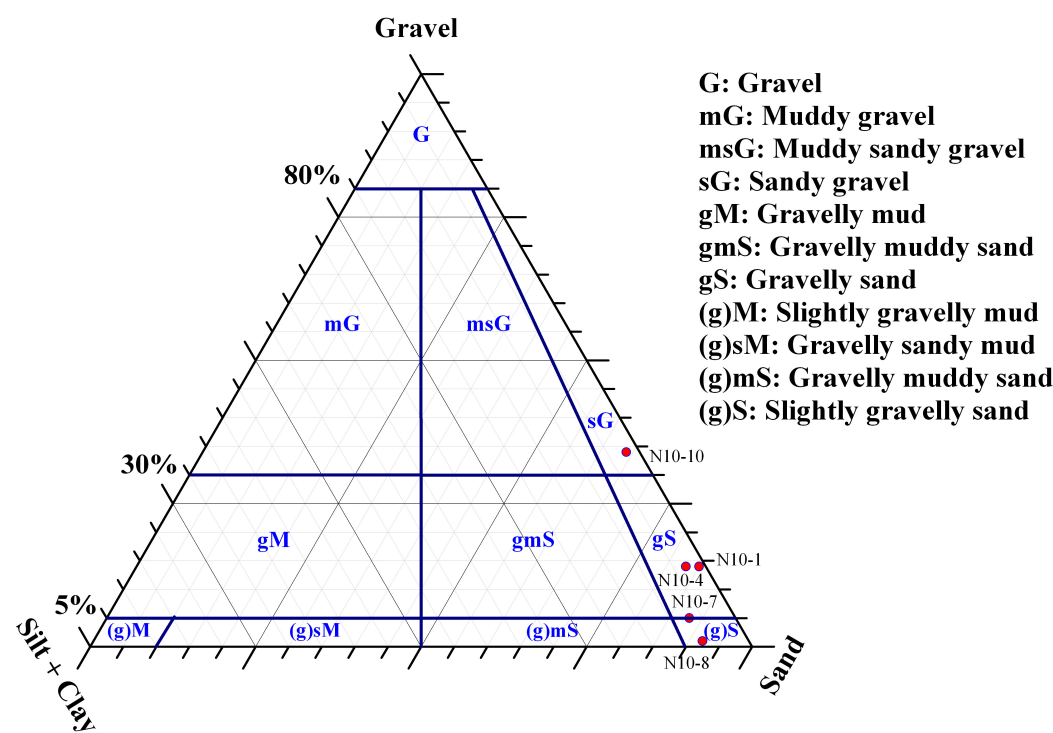

Fig. 4. Ternary diagram on the basis of gravel/sand/(silt+clay) ratios for the textural classification of the cave sediments analyzed according to Folk et al. (1970).

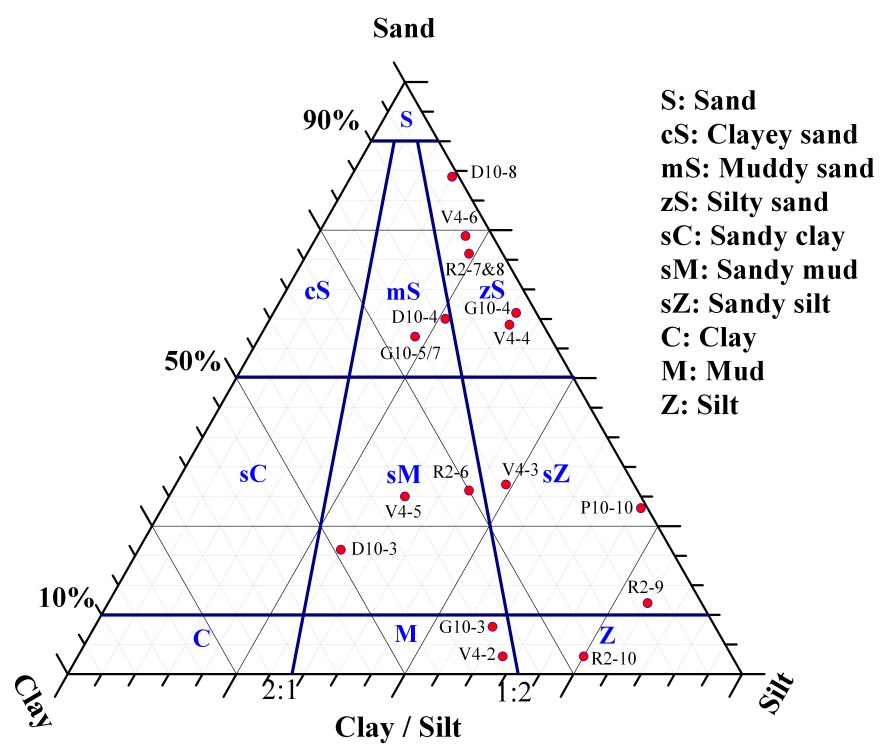

Fig. 5. Ternary diagram on the basis of sand/silt/clay ratios for the textural classification of the cave sediments analyzed according to Folk et al. (1970).

\section{Mineralogical composition}

The semi-quantitative mineralogical composition of the samples analyzed is presented in Tables 3 and 4. The quartz content varies significantly, ranging from traces (sample V4-2) to 35\% (sample R2-7). An analogous variation is observed for the plagioclase content, too. Phyllosilicates are present in significant amounts in all the examined sediments. Micas (+ chlorite + serpentine) are present in all samples. Talc content varies from traces up to $30 \%$ (sample R2-6). Accessory ferromagnesian minerals, such as olivine (forsterite), pyroxene and amphibole (tremolite), are common almost in all samples. Pyrite exists in most of the samples. The presence of minerals of volcanic origin, such as cristobalite and zeolite, is scarce. They are found only in the sample N10-1.

In most of the siliciclastic sediments of the cave, calcite and dolomite, both of detrital origin, are found. The total amount of these two carbonate minerals varies from 3\% (sample P10-10) to 93\% (sample P10-9). The carbonate minerals aragonite (21\%) and Mg-kutnohorite (27\%), both of chemical origin, have been detected in one sample (Ia-1), beyond its detrital carbonate components of dolomite (27\%) and calcite (25\%).

Muscovite (+sericite+illite) and chlorite (+serpentine) predominate in the $<20 \mu \mathrm{m}$ fraction of some fine grained samples analyzed. Talc follows in lesser amounts. The presence of other minerals is limited because of the small grain size of this fraction (Table 4).

The distribution of the minerals within each stratigraphic column is demonstrated in Fig. 7. The mineral assemblages $[\mathrm{Q}+\mathrm{F}(\mathrm{Kf}+\mathrm{P})+\mathrm{M}]$ and $(\mathrm{T}+\mathrm{O} 1+\mathrm{Px}+\mathrm{Am})$ coincide in variation in the stratigraphic columns. The assemblage $(\mathrm{D}+\mathrm{C})$ presents a reverse trend comparing it to the previous ones.

\section{Paleontological findings}

Micromammalian remains were found in two chronologically different localities within the Loutra Almopias Cave: such fossils have been found in different beds of all the excavated sites in the cave floor (sites V4-5, N10-4, G10-5, G106, G10-7, D10-3, R1-2, R2-4) as well as within the sediments of an elevated site, $5 \mathrm{~m}$ above the cave floor (site LAC Ia). After detailed excavation processes and treatments of the sediments, a large number of micromammalian teeth and bones were yielded (e.g., insectivores, rodents, lagomorphs). In total 31 species have been recognized within the sediments at both localities (Chatzopoulou, 2014). Both faunas show a mixing of typical Pleistocene species (cool climatic conditions) with Holocene species (warm climatic conditions). The faunal composition and the absolute dating of fossils and sediments confirm that the fauna from the cave floor sediments may be contemporary or slightly younger than the macromammalian fauna from the same sites, which is dominated by the cave-bear species Ursus ingressus, representing the Middle Würm $(42,500 \mathrm{BP})$ to Last Glacial Maximum (Rabeder et al., 2006), whereas the fauna from LAC Ia is younger $(14,500-13,000 \mathrm{BP})$, representing a cold period of Last Glacial (Older/Younger Dryas) before the Holocene Epoch (Rabeder, pers. comm.).

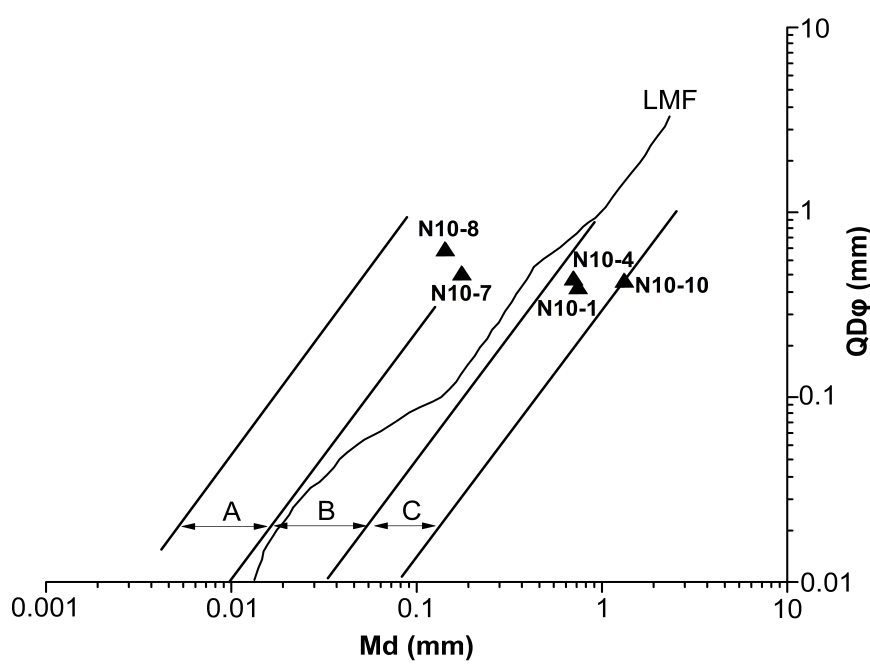

Fig. 6. Discrimination diagram for depositional environments according to $\mathrm{Pe} \&$ Piper (1975). $A$ = glacial deposits, $B=$ mudflows, and $C=$ fluvial deposits. LMF = Limit of Mud Flows. Other symbols as in Table 1. 
Table 3. Semi-quantitative mineralogical composition (wt.\%) by XRD of the bulk cave sediments analyzed.

\begin{tabular}{|c|c|c|c|c|c|c|c|c|c|c|c|c|c|c|c|c|c|}
\hline Column & Sample & $\begin{array}{c}\text { Depth } \\
\text { (cm) }\end{array}$ & D & $\mathbf{C}$ & $\mathbf{Q}$ & $\mathbf{K f}$ & $\mathbf{P}$ & $\mathbf{M}$ & $\mathbf{T}$ & 01 & $\mathbf{P x}$ & Am & Py & $\mathbf{C r}$ & $\mathbf{Z}$ & $\mathbf{A r}$ & $\mathbf{K n}$ \\
\hline \multirow{11}{*}{ LAC I } & N10-1 & -89 & - & - & 23 & - & 6 & 41 & - & - & 8 & - & - & 13 & 9 & - & - \\
\hline & $\mathrm{N} 10-2$ & -92 & 90 & 1 & 2 & 1 & 1 & 3 & 1 & 1 & - & - & - & - & - & - & - \\
\hline & N10-4 & -105 & 9 & 4 & 19 & 5 & 5 & 23 & 6 & 13 & 4 & 5 & 7 & - & - & - & - \\
\hline & N10-6 & -127 & 35 & 10 & 7 & 1 & 2 & 34 & 6 & 2 & 1 & 2 & - & - & - & - & - \\
\hline & N10-7 & -153 & 10 & - & 29 & - & 19 & 18 & 13 & - & 3 & 4 & 4 & - & - & - & - \\
\hline & N10-8 & -170 & 31 & 16 & 11 & - & 4 & 24 & 7 & - & 3 & 4 & & - & - & - & - \\
\hline & N10-9 & -198 & 62 & 4 & 2 & 1 & 5 & 17 & 6 & 1 & - & 1 & 1 & - & - & - & - \\
\hline & N10-10 & -247 & 34 & 5 & 13 & - & 4 & 13 & 23 & 2 & - & 3 & 3 & - & - & - & - \\
\hline & P10-9 & -84 & 91 & 2 & 4 & - & 1 & 2 & - & - & - & - & - & - & - & - & - \\
\hline & $\mathrm{P} 10-8$ & -87 & 32 & - & 28 & - & 9 & 15 & 5 & 6 & 1 & 4 & - & - & - & - & - \\
\hline & P10-10 & -93 & 3 & - & 31 & 3 & 3 & 44 & 5 & 4 & 3 & - & 4 & - & - & - & - \\
\hline \multirow{6}{*}{ LAC Ib } & V4-2 & -58 & 2 & 89 & $\operatorname{tr}$ & - & - & 5 & - & - & - & 4 & - & - & - & - & - \\
\hline & V4-3 & -73 & 24 & 48 & 12 & - & 2 & 14 & $\operatorname{tr}$ & - & - & - & - & - & - & - & - \\
\hline & V4-4 & -88 & 54 & 8 & 16 & - & 3 & 19 & $\operatorname{tr}$ & - & - & - & - & - & - & - & - \\
\hline & V4-5 & -128 & 6 & - & 15 & 3 & 11 & 37 & 9 & 5 & 3 & 6 & 5 & - & - & - & - \\
\hline & V4-6 & -148 & 52 & 1 & 4 & 1 & 22 & 8 & 8 & - & 1 & 2 & 1 & - & - & - & - \\
\hline & V4-7 & -197 & 21 & 37 & 4 & - & 3 & 21 & 11 & - & - & 3 & $\operatorname{tr}$ & - & - & - & - \\
\hline \multirow{5}{*}{ LAC Ic } & G10-3 & +5 & 19 & 26 & 22 & - & 3 & 28 & - & 2 & - & - & - & - & - & - & - \\
\hline & G10-4 & -25 & 50 & 3 & 9 & - & 10 & 18 & 6 & 1 & 2 & 1 & - & - & - & - & - \\
\hline & G10-5 & -60 & 18 & 32 & 26 & - & 5 & 7 & - & 4 & - & 4 & 4 & - & - & - & - \\
\hline & G10-6 & -105 & 40 & 1 & 19 & 1 & 5 & 23 & 4 & 3 & - & 4 & - & - & - & - & - \\
\hline & G10-7 & -135 & 30 & 2 & 25 & & 14 & 19 & 2 & - & - & 7 & 1 & - & - & - & - \\
\hline \multirow{7}{*}{ LAC II } & D10-1 & -75 & 32 & 19 & 12 & - & 3 & 7 & 8 & 10 & - & 3 & 6 & - & - & - & - \\
\hline & D10-2 & -84 & - & - & 23 & - & 27 & 22 & 6 & 13 & 3 & 6 & - & - & - & - & - \\
\hline & D10-3 & -100 & 14 & 17 & 30 & - & 7 & 13 & 6 & 12 & - & 1 & - & - & - & - & - \\
\hline & D10-4 & -120 & - & 77 & 9 & - & 1 & 4 & - & 6 & - & $\operatorname{tr}$ & 3 & - & - & - & - \\
\hline & D10-5 & -140 & 43 & 28 & 6 & 1 & 8 & 12 & 2 & - & - & - & - & - & - & - & - \\
\hline & D10-7 & -220 & 39 & 3 & 20 & - & 5 & 14 & 8 & - & 4 & 4 & 3 & - & - & - & - \\
\hline & D10-9 & -240 & 42 & 13 & 14 & - & 3 & 12 & 8 & 2 & - & 4 & 2 & - & - & - & - \\
\hline \multirow{7}{*}{ LAC III } & R1-2 & -97 & 14 & 3 & 24 & - & 2 & 38 & 2 & 11 & - & - & 6 & - & - & - & - \\
\hline & R2-4 & -148 & - & - & 21 & - & 12 & 30 & 14 & 11 & - & 4 & 8 & - & - & - & - \\
\hline & R2-6 & -158 & 10 & 8 & 23 & - & 5 & 10 & 30 & 2 & 2 & 8 & 2 & - & - & - & - \\
\hline & R2-7 & -163 & - & - & 35 & - & 25 & 5 & 14 & 3 & 8 & 7 & 3 & - & - & - & - \\
\hline & $\mathrm{R} 2-8$ & -165 & 45 & 5 & 17 & - & 10 & 6 & 7 & - & - & 9 & 1 & - & - & - & - \\
\hline & R2-9 & -168 & 12 & 28 & 8 & 1 & 2 & 22 & 23 & - & - & 3 & 1 & - & - & - & - \\
\hline & $\mathrm{R} 2-10$ & -178 & 45 & 2 & 17 & - & 3 & 12 & 14 & 1 & 2 & 3 & 1 & - & - & - & - \\
\hline LAC Ia & Ia-1 & +420 & 27 & 25 & - & - & - & - & - & - & - & - & - & - & - & 21 & 27 \\
\hline
\end{tabular}

$\mathrm{D}$ = dolomite; $\mathrm{C}=$ calcite; $\mathrm{Q}=$ quartz; $\mathrm{Kf}=\mathrm{K}$-feldspar; $\mathrm{P}=$ plagioclase $\mathrm{M}$ = micas (+chlorite+serpentine); $\mathrm{T}$ = talc; $\mathrm{Ol}=$ olivine; $\mathrm{Px}=$ pyroxene; $\mathrm{Am}=$ amphibole; $\mathrm{Py}=$ pyrite $\mathrm{Cr}=$ cristobalite; $\mathrm{Z}=$ zeolite; $\mathrm{Ar}=$ aragonite; $\mathrm{Kn}=\mathrm{Mg}$-kutnohorite $\mathrm{tr}=\mathrm{traces}$.

Table 4. Semi-quantitative mineralogical composition (wt.\%) by XRD of the $<20 \mu \mathrm{m}$ fraction of selected fine grained cave sediments.

\begin{tabular}{|l|c|c|c|c|c|c|c|c|}
\hline \multicolumn{1}{|c|}{ Sample } & Q & F & M & Ch & T & Am & C & D \\
\hline N10-4 & - & - & 30 & 48 & 16 & 1 & - & 5 \\
\hline V4-3 & - & 1 & 33 & 46 & 18 & 2 & - & - \\
\hline G10-5 & 8 & 10 & 44 & 19 & 8 & 8 & 3 & - \\
\hline G10-6 & 4 & 2 & 41 & 37 & 10 & 6 & - & - \\
\hline D10-3 & 7 & - & 47 & 38 & 6 & 2 & - & - \\
\hline R1-2 & - & - & 52 & 41 & 7 & - & - & - \\
\hline
\end{tabular}

$\mathrm{Q}=$ quartz; $\mathrm{F}=$ feldspars $(\mathrm{Kf}+\mathrm{P}) ; \mathrm{M}=$ muscovite (+sericite+illite); $\mathrm{Ch}=$ chlorite (+serpentine); $\mathrm{T}=$ talc; Am = amphibole; $\mathrm{C}=$ calcite; $\mathrm{D}=$ dolomite. 

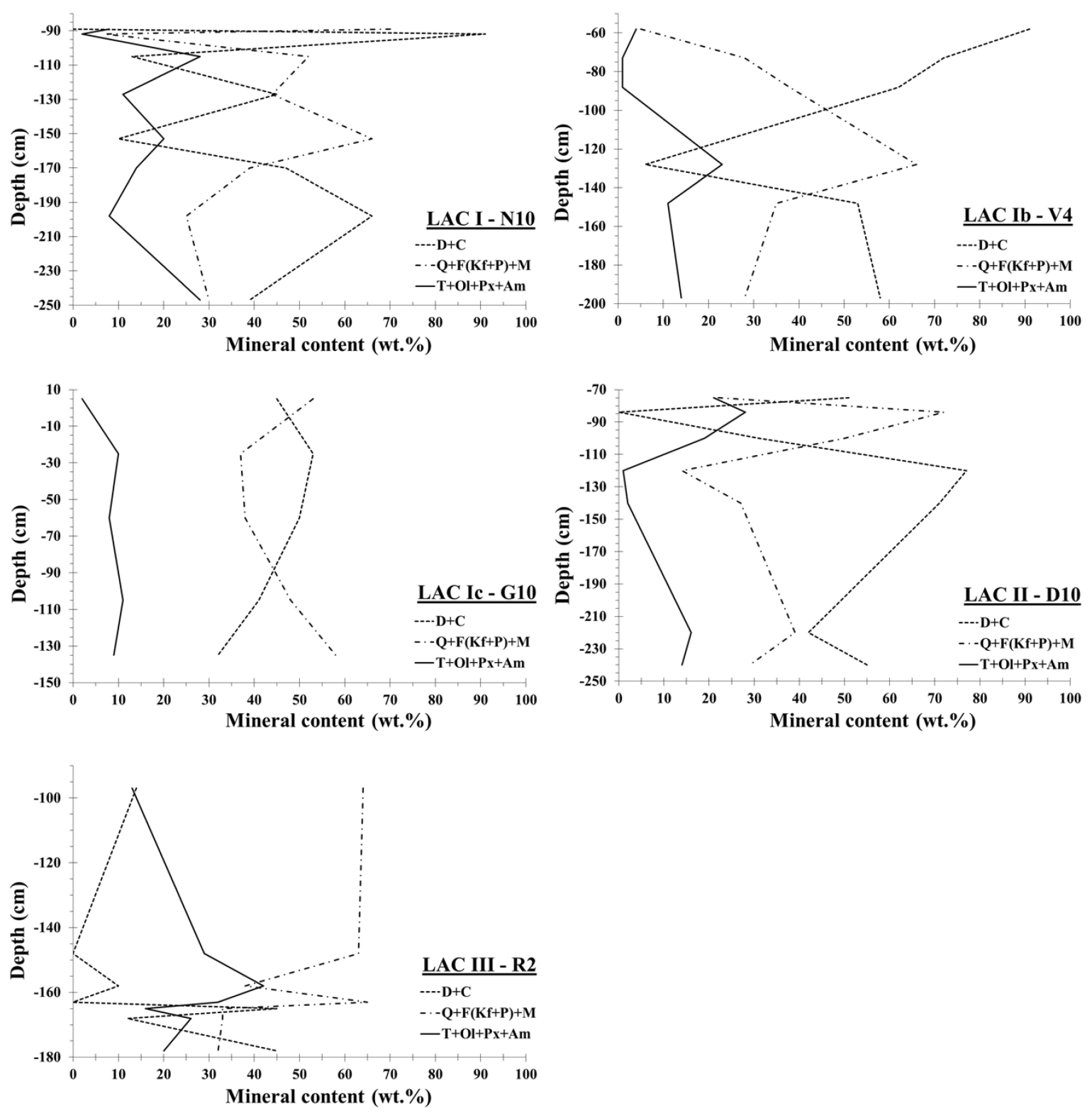

Fig. 7. Mineralogical variation in the stratigraphic columns. $F=$ feldspars $(\mathrm{Kf}+\mathrm{P})$. Other abbreviations as in Table 3.

The faunal composition from both sites comprises boreal, nemoral, mountain and steppe species characterizing a rather periglacial environment; the animals lived under cool and dry conditions, milder than the typical Alpine conditions, during the last Ice Age. However, the presence of fossils of Lepus timidus (mountain hare) in the locality LAC Ia is associated with the cool phase at the end of the last glacial period and represents the southernmost record of this species in Europe (Chatzopoulou et al., 2011). Today this species retreated northwards inhabiting Ireland and Scandinavia, while a local population maintained in the Alpine area as relict subspecies (Kurtén, 1968; Thulin, 2003). Thus, the presence of Lepus timidus clearly indicates a cold stage of Last Glacial (Older/Younger Dryas) before the onset of the warm Holocene Epoch.

\section{DISCUSSION}

Channel facies make up the bulk of the clastic sediments found in cave passages. When seen in stratigraphic section, they are found to consist of distinct beds of silts, sands, and gravels. However, bed lithology changes rapidly along the stratigraphic section (Bosch \& White, 2004). Such sediment facies and stratigraphic changes have been found in the Loutra Almopias Cave. Thalweg facies (coarse grained material from which most of the sand, silt and clay has been removed) have not been noticed. Slackwater facies are found in most cave deposits as laminated fine grained sediments (i.e., clay and silt) overlaying the channel deposits. This comprises the final layer of all the stratigraphic sections of the examined cave (Fig. 3).

Abundant carbonate sand-sized grains, pebbles and cobbles, composed of dolomite and calcite, were found in the loose sediments in most of the excavated sites. Their source must be attributed mainly to detrital contribution from the weathering and erosion of the surrounding carbonate rocks outside of the cave and to a much less extent to chemical precipitation in situ. In general, aragonite is less stable than calcite and at surface temperatures and pressures it is metastable and fairly readily inverts to calcite (Deer et al., 2013). From this point of view, sample Ia- 1 is of extreme interest; its content in aragonite $(21 \%)$ is indicative of its recent formation. In addition, the relatively rare carbonate mineral kutnohorite, isomorphous with 
dolomite, was found for first time in a Greek cave composing $27 \%$ of the sample Ia-1. Siphonial lenses (pods) of Mg-calcite, siderite, kutnohorite, ankerite with dispersed pyrite, have been found within the "ankeritized" marbles of the Lavrion peninsula of Attica Greece (Marinos \& Petrascheck, 1956). In addition, kutnohorite was found in the gangue minerals of the disseminated sulfide ore of Madem Lakkos, Chalkidiki Greece (Nebel et al., 1991). Kutnohorite has been found in a wide range of environments, including lowtemperature sedimentary rocks, pedogenic nodules and cave deposits, associated with aragonite and formed under reducing environments (Cancian \& Princivalle, 1991). Buck et al. (2004) found kutnohorite with anhydrite and calcite/Mg-calcite under arid climate. They consider the co-existence of kutnohorite and calcite/Mg-calcite indicative of fluctuations in the soil environment with depth, resulted from seasonal or glacial/interglacial climate change. This is in accordance with the presence of Lepus timidus in LAC Ia, a rather psychrophilic species (Chatzopoulou et al., 2011). Remarkable is the complete absence of carbonate constituents from samples N10-1, D10-2, R2-4, and R2-7.

Quartz is present in almost all samples. This is attributed to its abundance in the surrounding metamorphic rocks and to its mechanical and chemical resistance. Especially, the presence of cristobalite in one sample (N10-1), along with zeolite, is indicative of clastic contribution from the weathering of the neighboring volcanic rocks. On the other hand, plagioclase is present in greater amounts than $\mathrm{K}$-feldspar, corresponding to a regime of rapid weathering of the source rocks and deposition near them (Folk, 1974; Blatt et al., 1980). Plagioclase predominates in excess to K-feldspar in the surrounding source rocks. The presence of olivine, along with pyroxene, talc and serpentine in the floor sediments of the cave is indicative of a mafic source. Particularly, talc occurs in low-grade metamorphic ultrabasic rocks, in hydrothermally altered ultrabasic rocks and in contact metamorphosed siliceous dolomites (Deer et al., 2013). In ultrabasic rocks the talc is usually accompanied by serpentine and olivine, whereas in siliceous dolomites it is accompanied by tremolite, chlorite, magnesite, dolomite and quartz. Talc also is the result of weathering of ultrabasic rocks (i.e., alteration of clinopyroxenes), leading to the final assemblage serpentine+talc+spinel (Velde, 1985). In the area surrounding the cave, ultrabasic rocks and talc schists outcrop, leading to a mixed source for the detrital talc found in the samples. Chlorite is largely unstable in most weathering environments and its presence in sediments, as it happens in the cave studied, is certainly detrital in origin (Velde, 1985).

Amphibole (tremolite) and pyroxene are found in most of the samples in minor amounts. In general, amphibole is more abundant than pyroxene. These minerals are indicative of a metamorphic source and belong to the metastable group of heavy minerals (Folk, 1974). Metamorphic rocks rich in such minerals predominate in the surrounding area. Although these ferromagnesian minerals are very susceptible to weathering, their presence means inadequate time and distance for physical sorting, mechanical abrasion and dissolution (Morton \& Hallsworth, 1999). This conclusion is enhanced by the extensive presence of tiny non-oxidized crystals of pyrite in most of the cave sediments. These pyrite crystals are largely due to the weathering of the adjacent phyllites.

The samples must be mineralogically immature. Beyond their high content in quartz, feldspars and carbonates, theyextensivelycontain theferromagnesian minerals amphibole (tremolite), pyroxene and olivine (forsterite). The feldspars and heavy mineral content strengthen the hypothesis of deposition mostly under the action of physical weathering (Suttner \& Dutta, 1986). In addition, the presence of unstable minerals (i.e., pyroxene, plagioclase) along with semi-stable ones (i.e., amphibole, orthoclase) indicates the absence of chemical weathering (Garzanti et al., 2004). The absence of kaolinite along with the extensive presence of primary minerals, mean no intense weathering (Folk, 1974). Furthermore, the previous observations designate weathering of the source rocks under a tectonically active regime (Boggs, 2009).

In northern Greece glacial deposits have been recorded on the Mountain Range of Pindus (Mount Smolikas), on Mount Olympus, and on Mount Voras (Hughes et al., 2006; Smith et al., 2006; Bathrellos et al., 2014, 2017). The studied cave is located at the eastern slopes of Mount Voras $(2,524 \mathrm{~m})$, the $3^{\text {rd }}$ highest and the northernmost in Greece. Bathrellos et al. (2017) have found four inactive cirques of limestone lithology at the eastern slope of Mount Voras. The depositional environment of the cave sediments analyzed from chamber N10 is mostly fluvial as it is shown in Fig. 6. One sample may be considered glacial deposit. We strongly believe that more samples of glacial origin exist it other chambers. This finding means that colder climatic conditions prevailed during the Upper Pleistocene in the area in relation to modern time. Late Pleistocene bear bones studied by carbon and oxygen isotope analysis for paleoclimatic reconstruction led to the same conclusion (Zisi et al., 2010).

Sediment erosion inside the cave may have happened during episodes of flush flooding, which occurred in intermediate climatic conditions, not wet enough to favor speleothems formation and not too dry to allow slope erosion and sediment transport into the cave (Auler et al., 2009). Due to the low rate of Mount Voras denudation, cave passages will remain within the range of sediment infill and erosion for a much longer time, probably more than one glacialinterglacial cycle.

The great variation in the mineral content of the stratigraphic columns (Fig.7) is indicative of variations in the clastic load transported and deposited inside the cave. Both primary and accessory mineral content is variable. According to Blatt et al. (1980) such mineral assemblages are indicative of their source. The gravelsized detritus of various lithologies found in the cave sediments demonstrates episodes of a higher-energy environment and vicinity of this detritus to the source area (Reineck \& Singh, 1986). 
The extensive presence of siliciclastic minerals in all columns and in all beds, demonstrates that the detrital supply from the weathering of the surrounding rocks of various mineralogical composition was happening with aperiodic hiatuses.

One sample shows that the detritus at least in one unconformably lain bed has a glacial origin (N10-8). This sample and Ia- 1 record two different cold stages of Upper Pleistocene; N10-8 was laid before 42,500 BP and Ia-1 accumulated between 14,500 BP and 13,000 BP (Chatzopoulou et al., 2011).

\section{CONCLUSIONS}

The floor sediments of Loutra Almopias Cave are composed of poorly sorted sand-sized grains, pebbles and cobbles mainly of dolomitic and calcitic composition and mud in most of them, designating these sediments as texturally submature. Furthermore, they are mineralogically immature due to the extensive presence of the ferromagnesian minerals amphibole (tremolite), pyroxene and olivine (forsterite), beyond their high content in quartz, feldspars and carbonates.

The presence of quartz, feldspars, micas, talc, forsterite, pyroxene and tremolite means that the phyllites, gneisses, schists, ophiolitic rocks and the clastic Mariam Formation of the Almopia Zone, along with the flysch of the neighboring Pelagonian Zone, are the main detrital load source. The extensive presence of calcite and dolomite grains also designates the carbonate rocks of the Almopia and Pelagonian Zones as primary sources. The absolute absence of aragonite (except sample Ia-1) in the floor sediments means that the carbonate constituents present are primarily of detrital origin. The presence of minor amounts of calcite of chemical origin can not be excluded. Kutnohorite is found for first time in a Greek cave. The scarce presence of zeolite and cristobalite, demonstrates minor contribution of detrital load from the surrounding volcanic rocks.

All these findings lead to the conclusion of a mixed provenance for the sediments of the Loutra Almopias Cave. They are constituted mainly of the weathering detritus from the Alpine metamorphic basement outcropping N-NE (with metamorphic rocks rich in quartz, plagioclase, micas and ferromagnesian minerals) and the carbonate rocks outcropping NW-W of the cave area. Detritus from flysch was added, too. The acid volcanic rocks outcropping in the surrounding area, have contributed clastic load to a lesser extent.

The sediments were deposited near their source, after rapid weathering and erosion of the source rocks, under a tectonically active regime. The extensive presence of pebbles and cobbles in some beds demonstrates episodes of intense hydraulic conditions. The great variation in the mineral content of the stratigraphic columns is indicative of variations in the clastic load, due to the different weathering intensity periods.

Fossils of Lepus timidus (mountain hare) found in the locality LAC Ia represent the southernmost record of this species in Europe. Its presence signifies a cool phase at the end of the last glacial period before the onset of the warm Holocene Epoch.

The deposited detritus on the floor of the different cave chambers is mostly fluvial in origin. However, one sample shows that the detritus at least in one unconformably lain bed has a glacial origin. This study enhances other results that colder climatic conditions prevailed during Upper Pleistocene in the adjacent to the cave region in relation to modern time.

\section{ACKNOWLEDGEMENTS}

We are very grateful to the anonymous reviewers whose constructive and thorough reviews improved greatly a first version of this text. Furthermore, we are very indebted to Hariklia Skilodimou for the adjustment of Figure 1 to the needs of this paper. We express our sincere thanks to Professor Antonis Koroneos, Director of the Department of MineralogyPetrology-Economic Geology, School of Geology, Aristotle University of Thessaloniki, where all the analytical work was carried out.

\section{REFERENCES}

Auler A.S., Smart P.L., Wang X., Pilo L.B., Edwards R.L. \& Cheng H., 2009 - Cyclic sedimentation in Brazil caves: Mechanisms and palaeoenvironmental significance. Geomorphology, 106: 142-153. https://doi.org/10.1016/j.geomorph.2008.09.020

Bathrellos G.D., Skilodimou H.D. \& Maroukian H., 2014 - The spatial distribution of Middle and Late Pleistocene cirques in Greece. Geografiska Annaler: Series A, Physical Geography, 96: 323-338. https://doi.org/10.1111/geoa.12044

Bathrellos G.D., Skilodimou H.D. \& Maroukian H., 2017 - The significance of tectonism in the glaciations of Greece. In: Hughes P.D. \& Woodward J.C. (Eds.), Quaternary Glaciation in the Mediterranean Mountains. Geological Society, London, Special Publication, 433: 237-250. https://doi.org/10.1144/SP433.5

Blatt H., Middleton G. \& Murray R., 1980 - Origin of sedimentary rocks ( $\left.2^{\text {nd }} E d.\right)$. Prentice-Hall Inc., New Jersey, $782 \mathrm{p}$.

Boggs Jr.S., 2009 - Petrology of sedimentary rocks $\left(2^{\text {nd }}\right.$ Ed.). Cambridge University Press, New York, 600 p. https://doi.org/10.1017/CBO9780511626487

Bosch R.F. \& White W.B., 2004 - Lithofacies and transport of clastic sediments in karstic aquifers. In: Sasowsky I.D. \& Mylroie J. (Eds.), Studies of cave sediments: Physical and chemical records of paleoclimate. Kluwer Academic/Plenum, New York, 1-22.

https://doi.org/10.1007/978-1-4419-9118-8_1

Buck B.J., Merkler D., Mrozek S., Harrison B. \& Lato L., 2004 - Spheroidal Dolomite, Mg-Calcite, and MgKutnohorite, Death Valley CA, USA: Implications for Genesis and Paleoenvironmental Interpretations. In: Kapur S., Akca E., Montanarella L., Ozturk A. \& Mermut A. (Eds.), $12^{\text {th }}$ International Meeting on Soil Micromorphology. European Communities, EUR 21275 EN/2., Adana Turkey, p. 86-88.

Cancian G. \& Princivalle F., 1991 - Kutnohorite from Caverna Pocola soil (Trieste Karst, Italy). Periodico di Mineralogia, 60: 15-20.

Chatzopoulou K., 2005 - The stratigraphy from the Loutra Arideas Bear-Cave (Pella, Macedonia, Greece) 
with emphasis on two new chambers. In: Petreas Ch. (Ed.), Proceedings of the $14^{\text {th }}$ International Congress of Speleology. Kalamos, Greece, 1: 49-51.

Chatzopoulou K., 2014 - The micromammals of the Quaternary deposits from cave A, Loutra Almopias (Pella, Northern Greece). Stratigraphy-taphonomypaleoenvironment. Unpublished $\mathrm{PhD}$ Dissertation, Aristotle University of Thessaloniki, 377 p. (in Greek with English abstract).

Chatzopoulou K., Tsoukala E. \& Vlachos E., 2011 The contribution of Late Pleistocene micromammalian fauna in the interpretation of the taphonomical history of the Loutra Almopias Cave (Macedonia, Greece). International Colloquium: the Late Cenozoic Mammals: Fossil Record, Biostratigraphy, Paleoecology, Praha, Abstract Book, p. 1-2.

Deer W.A., Howie R.A. \& Zussman J., 2013 - An introduction to the rock-forming minerals ( $3^{\text {rd }}$ Ed.). Mineralogical Society of London, 498 p.

Eleftheriadis G., 1977 - Contribution in the study of the volcanogenic rocks of South Almopia. Unpublished PhD Dissertation, Aristotle University of Thessaloniki, 173 p. (in Greek with English abstract).

Folk R.L., 1974 - Petrology of sedimentary rocks. Hemphill Publishing Co., Austin, 170 p.

Folk R.L., Andrews P.B. \& Lewis D.W., 1970 - Detrital sedimentary rock classification and nomenclature for use in N. Zealand. New Zealand Journal of Geology and Geophysics, 13: 937-968.

https://doi.org/10.1080/00288306.1970.10418211

Garzanti E., Vezzoli G., Ando S., France-Lanord C., Singh S.K. \& Foster G., 2004 - Sand petrology and focused erosion in collision orogens: The Brahmaputra case. Earth and Planetary Science Letters, 220: 157-174. https://doi.org/10.1016/S0012-821X(04)00035-4

Hower J., Eslinger E.V., Hower M.E. \& Perry E.A., 1976 - The mechanism of burial metamorphism of argillaceous sediment. Geological Society of America Bulletin, 87: 727-757. https://doi.org/10.1130/00167606(1976)87\%3C725:MOBMOA\%3E2.0.CO;2

Hughes P.D. \& Woodward J.C., 2016 - Quaternary glaciation in the Mediterranean mountains: a new synthesis. Geological Society of London, Special Publication, 433, 23 p. https://doi.org/10.1144/SP433.14

Hughes P.D., Woodward J.C. \& Gibbard P.L., 2006 - The last glaciers of Greece. Zeitschrift für Geomorphologie, 50 (1): 37-61.

Jackson M.L., 1974 - Soil chemical analysis. Advance course. Madison, Wisconsin, $690 \mathrm{p}$.

Kabouroglou E.M. \& Chatzitheodorou Th., 1999 Geomorphological changes and sedimentation in the cave A (Agiasma) of Loutraki (Pella, Macedonia, Greece). In: Hellenic Geographical Society (Ed.), Proceedings of the $5^{\text {th }}$ Panhellenic Conference. Athens, 83-93 (in Greek).

Kabouroglou E., Bassiakos Y. \& Bouzas D., 2006 Paleontological-sedimentological excavation research in 2004 and dating studies of Cave A Loutraki Aridea. In: Adam-Veleni P. \& Tzanavari K. (Eds.), The archaeological work in Macedonia and Thrace. Ministry of Culture \& Aristotle University of Thessaloniki, 18: 573-589 (in Greek).

Kolios N., Innocenti F., Manetti P., Peccerillo A. \& Giulani O., 1980 - The Pliocene volcanism of the Voras Mt (Central Macedonia, Greece). Bulletin Volcanologique, 43 (3): 553-568.

https://doi.org/10.1007/BF02597692

Kurtén B., 1968 - Pleistocene mammals of Europe. Aldine Publishing Co., Chicago, 330 p.
Lazaridis G., 2006 - Almopia Speleopark (Pella, Macedonia, Greece): Morphology-speleogenesis of the caves. In: Tsoukala E. \& Rabeder G. (Eds.), Scientific annals. School of Geology, Aristotle University of Thessaloniki, 98: 33-40.

Marinos G.P. \& Petrascheck W.E., 1956 - Laurium. Geological and Geophysical Research, 4 (1): 1-247.

Moore D.M. \& Reynolds R.C., 1997 - X-ray diffraction and the identification and analysis of clay minerals $\left(2^{\text {nd }}\right.$ Ed.). Oxford University Press, New York, 378 p.

Morton A.C. \& Hallsworth C.R., 1999 - Processes controlling the composition of heavy mineral assemblages in sandstones. Sedimentary Geology, 124: 3-29. https://doi.org/10.1016/S0037-0738(98)00118-3

Mountrakis D., 1976 - Contribution in the geology of the northern boundary of the Axios and Pelagonian Zones in the area of K. Loutraki - Orma (Almopia). Unpublished $\mathrm{PhD}$ Dissertation, Aristotle University of Thessaloniki, 164 p. (in Greek with English abstract).

Nebel M.L., Hutchinson R.W. \& Zartman R.E., 1991 Metamorphism and polygenesis of the Madem Lakkos polymetallic sulfide deposit, Chalkidiki, Greece. Economic Geology, 86: 81-105. https://doi.org/10.2113/gsecongeo.86.1.81

Pe G.G. \& Piper J.W., 1975 - Textural recognition of mudflow deposits. Sedimentary Geology, 13: 303-306. https://doi.org/10.1016/0037-0738(75)90039-1

Pettijohn F.J., Potter P.E. \& Siever R., 1987 - Sand and sandstone (2 ${ }^{\text {nd }}$ Ed.). Springer-Verlag, New York, 553 p. https://doi.org/10.1007/978-1-4612-1066-5

Rabeder G., Tsoukala E. \& Kavcik N., 2006-Chronological and systematic position of cave bears from Loutra Arideas (Macedonia, Greece). In: Tsoukala E. \& Rabeder G. (Eds.), Scientific annals. School of Geology, Aristotle University of Thessaloniki, 98: 69-73.

Reineck H.-E. \& Singh I.B., 1986 - Depositional sedimentary environments ( $2^{\text {nd }}$ Ed.). Springer-Verlag, New York, 551 p.

Smith G.W., Nance R.D. \& Genes A.N., 2006 - Pleistocene glacial history of Mount Olympus, Greece: Neotectonic uplift, equilibrium line elevations, and implications for climatic change. United States Geological Survey, Special Paper, 409: 157-174.

https://doi.org/10.1130/2006.2409(09)

Suttner L.J., 1974 - Sedimentary petrographic provinces: an evaluation. In: Ross C.A. (Ed.), Paleogeographic provinces and provinciality. Special Publication, Society of Economic Paleontologists and Mineralogists, 21: 75-84. https://doi.org/10.2110/pec.74.21.0075

Suttner L.J. \& Dutta P.K., 1986 - Alluvial sandstone composition and paleoclimate, I. Framework mineralogy. Journal of Sedimentary Petrology, 56 (3): 329-345. https://doi.org/10.1306/212F8909-2B24-11D7$8648000102 \mathrm{C} 1865 \mathrm{D}$

Tsirambides A., 2006 - The sedimentology of the Bear Cave of Almopia Speleopark (Pella, Macedonia, Greece). In: Tsoukala E. \& Rabeder G. (Eds.), Scientific annals. School of Geology, Aristotle University of Thessaloniki, 98: 75-77.

Tsoukala E., Chatzopoulou K., Rabeder G., Pappa S., Nagel D. \& Withalm G., 2006 - Paleontological and stratigraphical research in Loutra Arideas Bear Cave (Almopia Speleopark, Pella, Macedonia, Greece). In: Tsoukala E. \& Rabeder G. (Eds.), Scientific annals. School of Geology, Aristotle University of Thessaloniki, 98: 41-67.

Thulin C.-G., 2003 - The distribution of mountain hares Lepus timidus in Europe: a challenge from brown hares L. europaeus? Mammal Review, 33 (1): 29-42. https://doi.org/10.1046/j.1365-2907.2003.00008.x 
Velde B., 1985 - Developments in sedimentolgy, no 40: Clay minerals: A physico-chemical explanation of their occurrence. Elsevier, Amsterdam, 426 p.

Vougioukalakis G., 1994 - The Pliocene volcanics of Mount Voras, Central Macedonia, Greece. Bulletin of Geological Society of Greece, 30 (1): 223-240.

Woodward J.C. \& Hughes P.D., 2011 - Glaciation in Greece: A new record of cold stage environments in the Mediterranean. In: Ehlers J., Gibbard P.L. \& Hughes
P.D. (Eds.), Developments in quaternary science. Amsterdam, 15, p. 175-198.

https://doi.org/10.1016/B978-0-444-53447-7.00015-5

Zisi N., Dotsika E., Tsoukala E., Giannakopoulos A. \& Psomiadis D., 2010 - Palaeoclimatic evolution in Loutra Arideas Cave (Almopia Speleopark, Macedonia N. Greece) by stable isotopic analysis of fossil bear bones and teeth. Bulletin of Geological Society of Greece, 43 (2): 958-964. https://doi.org/10.12681/bgsg.11261 